\title{
A New Problem for Western Romania: Metcalfa pruinosa emiptera:Flatidae
}

\author{
Ioana GROZEA $^{1 *}$, Alina GOGAN ${ }^{1}$, Mihai VLAD ${ }^{1)}$, Ana Maria VIRTEIU ${ }^{1)}$, Ramona STEF ${ }^{1)}$, Alin CARABET $^{11}$, \\ Snejana DAMIANOV ${ }^{1)}$, Teodora FLORIAN ${ }^{2)}$ \\ 1) Faculty of Agriculture, Agricultural Entomology Discipline, Department of Biology and Plant \\ Protection, Banat's University of Agricultural Sciences and Veterinary Medicine "Regele Mihai I al \\ României" from Timisoara, Calea Aradului, 119, Timisoara. \\ 2) Department of Environment and Plant Protection, University of Agricultural Science and Medicine \\ Veterinary, Calea Mănăștur 3-5, Cluj-Napoca, Romania. \\ ${ }^{*}$ Corresponding author, e-mail: ioana_entomol@yahoo.com
}

BulletinUASVM Horticulture 72(1) / 2015

Print ISSN 1843-5254, Electronic ISSN 1843-5394

Doi:10.15835/buasvmcn-hort:10337

\begin{abstract}
The cicada considered for this study is Metcalfa pruinosa (Say), called flatid plant hopper, a species that has recently caught the attention of experts in Romania. In year 2010, it was seen for the first time in the western part of country and it was identified by some routine observations. Is considered a non-native species knowing that originated in America. Objectives focused primarily exploration the territory in the western part, in order to report the first larval colonies and secondly identification of host plants. Observations were made during three years, 2011 to 2013 and included several points located near the western border. For monitoring of the immature stages (larvae, nymphs) direct observations were made in green spaces, parks, vineyards and orchards. Having in mind that larva is the most important stage, if we refer to damage plants, all our attention was directed to this. Somewhat, the results certify the polyphagism of this species, indicating numerous species of infested plants. Among, frequently infested with larval colonies, in green spaces, were Acer negundo, Acer pseudoplatanus, Acer campestre, Acer platanoides, Tilia cordata, Catalpa bignonioides, Juglans regia, Ligustrum vulgare, Hibiscus syriacus, etc. On the other hand, in the vineyards and orchards, plants affected were Malus domestica, Persica vulgaris, Prunus persica, Prunus armeniaca, Prunus domestica and Vitis vinifera. Currently, in the western part of Romania, over 50 host plants were identified, tree species (shrubs, trees, fruit -trees), culture plants (sunflower, soybean) and a lot of herbaceous species.
\end{abstract}

Keywords: colonies, invasive, Metcalfa pruinosa, polyphagous.

\section{INTRODUCTION}

The citrus flatid planthopper (Metcalfa pruinosa) is native to the Nearctic region, more specifically in Eastern North America, from Ontorio to Florida, Mexico and Cuba (Metcalf and Bruner, 1948). It is a common species on the american continent (Chittenden, 1900; Van Duzee, 1923; Weese, 1924; Willson and McPherson, 1981) and Europe (Grozea et al., 2011; Drosopoulos et al., 2004; Lauterer, 2002; Preda and Skolka; 2011; Sivic, 1991; Trenchev et al., 2006; Zangheri and
Donadini, 1980). In 2 years ago was raised in Asia, too (Kim et al., 2011).

The cicada is a species with a polifagism emphasized; in places of origin has a great range of host plants (over 100 plant species) and in Europe is recorded over 300 plant species (Alma et al., 2005; Wilson and Lucchi, 2000).

\section{MATERIALS AND METHODS}

The research has been carried out in a large territory of west part of Romania. Observations were made during three years, 2011 to 2013 and 
included several points located near the western border. These points have been covered in 3 counties (Timis, Caras Severin and Mehedinti) on the southern direction, starting from the reference County, Timis (where was the first outbreak) .

In term of monitoring activity. For Timis County were established follow point of observation (OP): Timissoara1 (green space + park); Timișoara2 -Didactic Experimental Resort-BUAVMT (vineyard+orchard); In Caras Severin County have been monitored less points, such as: Reșița (green space + park), Tirol (vineyard) and Caransebeș (green space+park). For Mehedinti County, the locality under observation was Drobeta-Turnu Severin (green space +park) (Fig. 1).

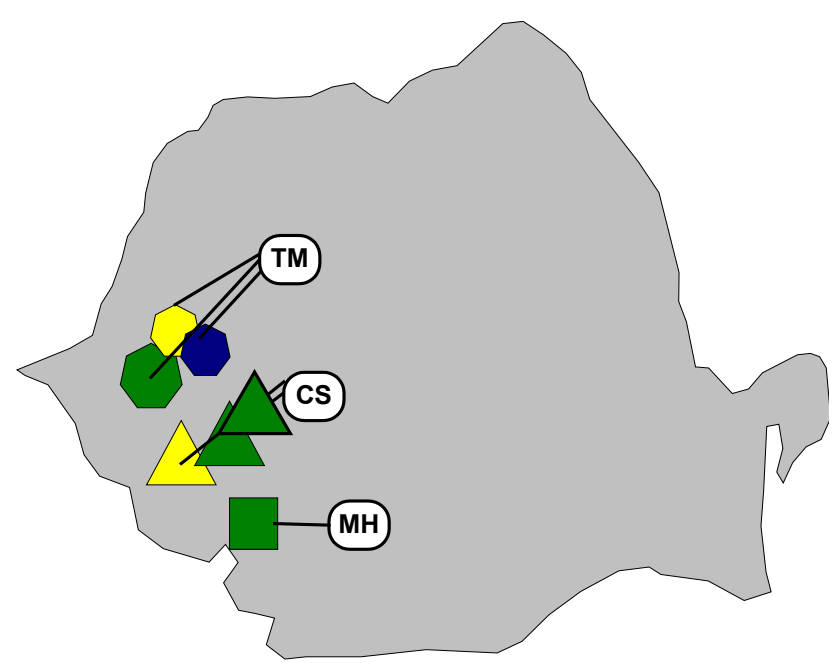

Fig. 1 Map of the points of observation in western counties (TM-Timis county, CS-Caras Severin county, MH-Mehedinti county); green points color represents green spaces and parks, yellow points represents vineyards and blue points show the orchards.

Each point was observation through the prism of larval colonies present on the leaves or young shoots of host plants (mentioned in specialty literature or from the native range of the green spaces, orchards or vineyards under studies).

For monitoring of the immature stages (larvae, nymphs) direct observations were made in green spaces, parks, vineyards and orchards. So, 3 readings were performed per year; a monthly reading ( 1 reading in July, 1 reading in August and
1 reading in September), usually in the middle of every month. Marking points of study was achieved with the help of GPS.

Regarding the establish of host plants. In this regard have been completed more stages: direct observations in order to establish a first set of host plants/PO; regular observations to identify new host plants; collection of samples (portions of sprouts, whole leaves, grapes) and finally transport and analyze in detail.

For both, monitoring and the range of host plants, there have been two types of observations, direct on plants in the area and their development and indirect, through detailed studies from the laboratory to the magnifying glass vision.

\section{RESULTS AND DISCUSSION}

First report of the invasive cicada, called Metcalfa pruinosa, in western Romania was recognized in year of 2010 (the place named Young Naturalists Resort Park of Timisoara (pointed with red color in the map) (Fig. 2). This is in fact

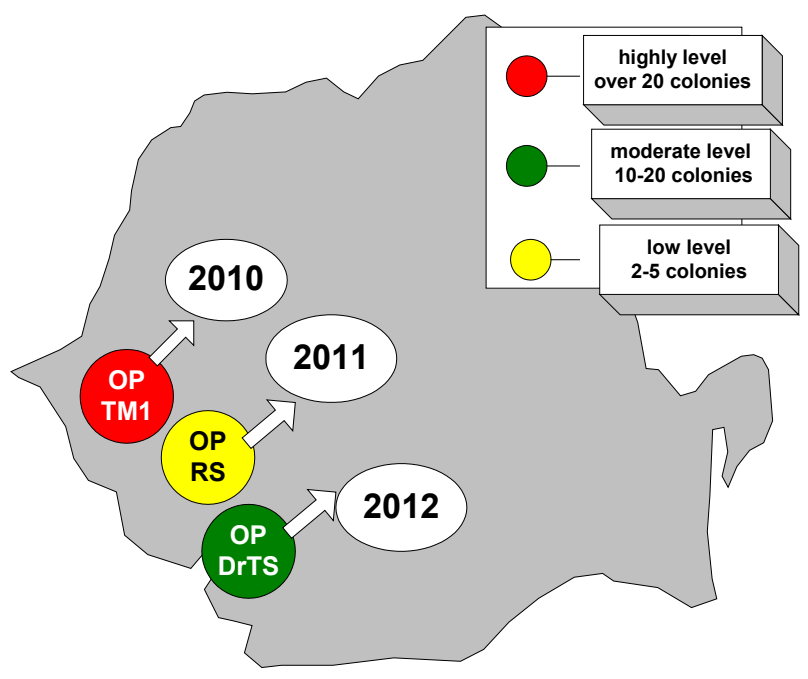

Fig. 2 Map of the first larval colonies, in western counties subject to the observations ((TM-Timis county, CS-Caras Severin county, MH-Mehedinti county);); red point is the first place where the insect was observed for the first time in west part of country.

the reference point of our studies.

The subsequently researches, carried out in the years 2011, 2012 nd 2013 revealed also the presence in other localities/points of observation. Next we make a short presentation of status in all points under observation. It is necessary to 
mention that in this paper data are presented only in Southern direction, from Timisoara (first point of occurence) to Danube.

Range of host plants. In OP/Timisoara1, plant species infested with larval colonies of Metcalfa were numerous, over 35 with high frequency folows: Tilia cordata, Ligustrum vulgare, Catalpa bignonioides; Fraxinus excelsior, Ficus carica, Hibiscus syriacus, Juglans nigra, Acer platanoides, Acer campestre, Acer negundo, Rosa sp.

In the three years of observations, in mixed plantation (vineyard and orchard) from OP/ Timisoara2 (DER-BUAVMT they highlighted the

Tab. 1 List of host plants for larvae of Metcalfa pruinosa in OP/Timisoara1- green space + park, in 20112013 period

\begin{tabular}{|c|c|c|c|c|}
\hline $\mathrm{N}$ & Family & Plant species & \multicolumn{2}{|c|}{ Colonies of larvae present on } \\
\hline 1 & Tiliaceae & Tilia cordata & \multicolumn{2}{|c|}{$\mathrm{x}$} \\
\hline 2 & \multirow{4}{*}{ Aceraceae } & Acer negundo & $\mathrm{x}$ & $\mathrm{x}$ \\
\hline 3 & & Acer pseudoplatanus & \multicolumn{2}{|c|}{$\mathrm{x}$} \\
\hline 4 & & Acer campestre & \multicolumn{2}{|c|}{$\mathrm{x}$} \\
\hline 5 & & Acer platanoides & \multicolumn{2}{|c|}{$\mathrm{x}$} \\
\hline 7 & \multirow{2}{*}{ Anacardiaceae } & Cotinus coggygria & \multicolumn{2}{|c|}{$\mathrm{x}$} \\
\hline 8 & & Rhus typhina & \multicolumn{2}{|c|}{$\mathrm{x}$} \\
\hline 9 & Rosaceae & Rosa sp & $\mathrm{x}$ & $\mathrm{x}$ \\
\hline 10 & Araliaceae & Hedera helix & $\mathrm{x}$ & $\mathrm{x}$ \\
\hline 11 & \multirow{2}{*}{ Adoxaceae } & Sambucus nigra & \multicolumn{2}{|c|}{$\mathrm{x}$} \\
\hline 12 & & Viburnum lantana & $\mathrm{x}$ & $\mathrm{x}$ \\
\hline 13 & Berberidaceae & Berberis thunbergii & $\mathrm{x}$ & $\mathrm{x}$ \\
\hline 14 & \multirow{2}{*}{ Buxaceae } & Buxus microphylla, & $\mathrm{x}$ & $\mathrm{x}$ \\
\hline 15 & & Buxus sempervirens & $\mathrm{x}$ & $\mathrm{x}$ \\
\hline 16 & \multirow{2}{*}{ Betulaceae } & Carpinus betulus & \multicolumn{2}{|c|}{$\mathrm{x}$} \\
\hline 17 & & Corylus avellana & \multicolumn{2}{|c|}{$\mathrm{x}$} \\
\hline 18 & Bignoniaceae & Catalpa bignonioides & \multicolumn{2}{|c|}{$\mathrm{x}$} \\
\hline 19 & Cornaceae & Cornus sp. & \multicolumn{2}{|c|}{$\mathrm{x}$} \\
\hline 22 & Caprifoliaceae & Heptacodium miconioides & \multicolumn{2}{|c|}{$\mathrm{x}$} \\
\hline 23 & Cannabaceae & Humulus lupulus & \multicolumn{2}{|c|}{$\mathrm{x}$} \\
\hline 24 & Fabaceae & Robinia pseudoacacia & \multicolumn{2}{|c|}{$\mathrm{x}$} \\
\hline 25 & Hydrangeaceae & Philadelphus sp., & \multicolumn{2}{|c|}{$\mathrm{x}$} \\
\hline 26 & \multirow{2}{*}{ Juglandaceae } & Juglans regia & \multicolumn{2}{|c|}{$\mathrm{x}$} \\
\hline 27 & & Juglans nigra & \multicolumn{2}{|c|}{$\mathrm{x}$} \\
\hline 28 & Malvaceae & Hibiscus syriacus & \multicolumn{2}{|c|}{$\mathrm{x}$} \\
\hline 29 & Moraceae & Ficus carica & $\mathrm{x}$ & $\mathrm{x}$ \\
\hline 30 & \multirow{2}{*}{ Oleaceae } & Fraxinus excelsior & & \\
\hline 31 & & Ligustrum vulgare & $\mathrm{X}$ & $\mathrm{x}$ \\
\hline 32 & Plantaginaceae & Plantago major & $\mathrm{x}$ & $\mathrm{x}$ \\
\hline 33 & Rосасеар & Pyrus communis & $\mathrm{x}$ & $\mathrm{x}$ \\
\hline 34 & kosaceae & Spiraea $x$ vanhouttei & & \\
\hline 35 & Sapindaceae & Aesculus hippocastanum & & \\
\hline 36 & Ulmaceae & Ulmus minor & $\mathrm{x}$ & $\mathrm{x}$ \\
\hline 37 & Vitaceae & Parthenocissus quinquefolia & $\mathrm{x}$ & $\mathrm{x}$ \\
\hline 38 & Magnoliaceae & Magnolia kobus & $\mathrm{x}$ & $\mathrm{x}$ \\
\hline
\end{tabular}


following plants: Vitis vinifera, Persica vulgaris, Malus domestica, Prunus persica, Prunus armeniaca, Prunus domestica (Tab. 2).

Insects was observed on all fruit trees in all the study, less than Prunus domestica which has not been observed in 2011 .

In point of observation $\mathrm{OP} /$ Resita the cicada had a smaller range plants of infested plants only on the leaves and young shoots, belonging to two species, Acer platanoides and Acer negundo (Tab.3).

Data obtained as a result of observations made in observation point from Drobeta Turnu Severin showed a large variety of infested plants. The larval colonies were fixed on plants which belong to the following botanical families: Tiliaceae, Rosaceae, Aceraceae, Betulaceae and Oleaceae (Tab. 4). So that, may be considered host plants, species like Acer negundo, Acer platanoides and Acer campestre.

It is important to note that at this point, the first report of the invasive insect was achieved only in the year 2012. In the first year of observations, 2011, the cicada was not present.

In point of observation OP/Tirol (vineyard) and $\mathrm{OP} /$ Caransebes (green space+park) the cicada has been found in no place researched and no plants.

Tab. 2 List of host plants for larvae of Metcalfa pruinosa in OP/Timisoara2- vineyard + orchard, in 2011-2013 period

\begin{tabular}{|c|c|c|c|c|}
\hline $\mathrm{N}$ & Family & Plant species & $\begin{array}{c}\text { Colonies } \\
\text { Leaves }\end{array}$ & $\begin{array}{l}\text { f larvae present on } \\
\text { Shoots/fruit stem }\end{array}$ \\
\hline 1 & \multirow{5}{*}{ Rosaceae } & Persica vulgaris & $\mathrm{x}$ & $\mathrm{x}$ \\
\hline 2 & & Prunus armeniaca & & $\mathrm{x}$ \\
\hline 3 & & Prunus persica & & $\mathrm{x}$ \\
\hline 4 & & Prunus domestica & $\mathrm{x}$ & $\mathrm{x}$ \\
\hline 5 & & Malus domestica & $\mathrm{x}$ & $\mathrm{x}$ \\
\hline 6 & Vitaceae & Vitis vinifera & $\mathrm{x}$ & $\mathrm{x}$ \\
\hline
\end{tabular}

Tab. 3 List of host plants for larvae of Metcalfa pruinosa in OP/Resita- green space + park, in 20112013 period

\begin{tabular}{ccccc}
\hline $\mathrm{N}$ & \multirow{2}{*}{ Family } & \multirow{2}{*}{ Plant species } & \multicolumn{2}{c}{ Colonies of larvae present on } \\
& & & Leaves & Shoots \\
\hline 1 & \multirow{2}{*}{ Aceraceae } & Acer negundo & $\mathrm{x}$ & $\mathrm{x}$ \\
\cline { 3 - 5 } & & Acer platanoides & $\mathrm{x}$ & $\mathrm{x}$ \\
\hline
\end{tabular}

Tab. 4 List of host plants for larvae of Metcalfa pruinosa in OP/Dr. Turnu Severin- green space + park, in years of 2012 and 2013

\begin{tabular}{|c|c|c|c|c|}
\hline $\mathrm{N}$ & Family & Plant species & \multicolumn{2}{|c|}{ Colonies of larvae present on } \\
\hline 1 & \multirow{3}{*}{ Aceraceae } & Acer negundo & $\mathrm{x}$ & $\mathrm{x}$ \\
\hline 2 & & Acer campestre & $\mathrm{x}$ & $\mathrm{x}$ \\
\hline 3 & & Acer platanoides & $\mathrm{x}$ & $\mathrm{x}$ \\
\hline 4 & Tiliaceae & Tilia cordata & \multicolumn{2}{|c|}{$\mathrm{x}$} \\
\hline 5 & Betulaceae & Carpinus betulus & \multicolumn{2}{|c|}{$\mathrm{x}$} \\
\hline 6 & Oleaceae & Fraxinus excelsior & \multicolumn{2}{|c|}{$\mathrm{x}$} \\
\hline 7 & Hydrangeaceae & Philadelphus sp. & \multicolumn{2}{|c|}{$\mathrm{x}$} \\
\hline
\end{tabular}




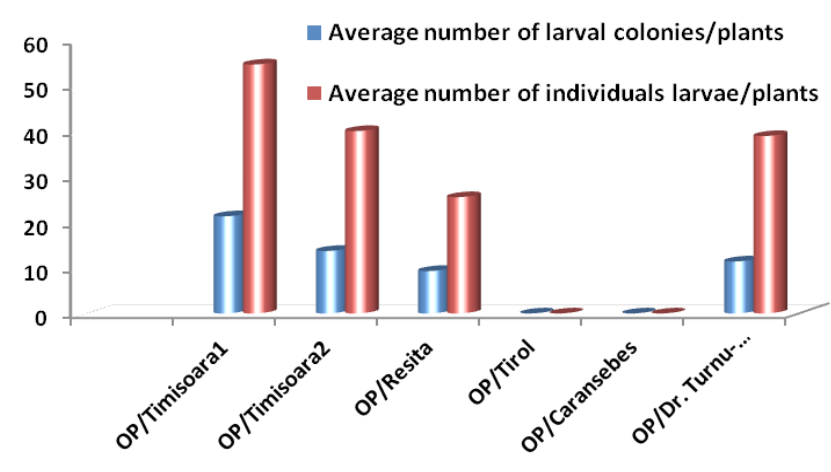

Fig. 3 The level of larval colonies and individuals larvae on plants, in several observation points from western Romania.

Colonies and larvae on plants. In Fig. 3 average values are represented in comparison mod, between populational level of the larvae and colonies present in the observation points. Far as in OP/Timisoara values are higher than in

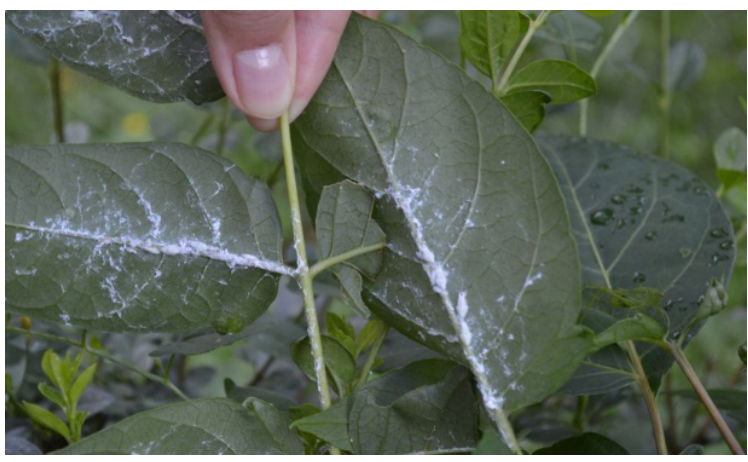

Fig. 1 Larvae and their waxy secretion on leaves

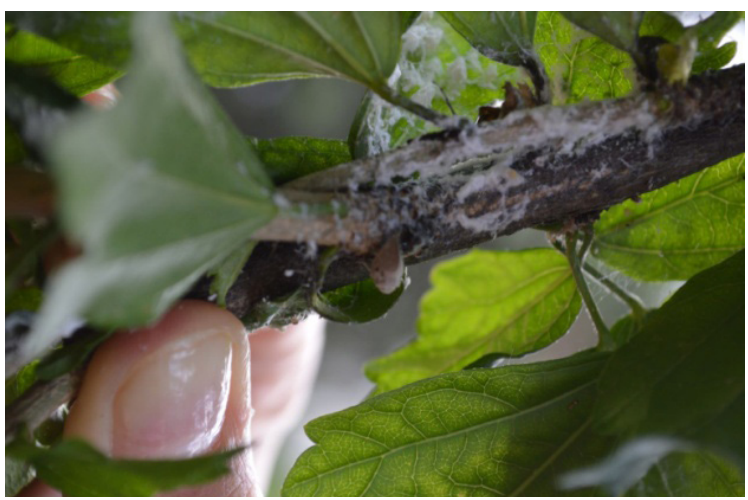

Fig. 3 Larval waxy secretion the shoot (indirect damage) other places. Explainable, maybe due to the fact that here was the first report of the insect and also, there exist one year advance ahead of other points (2010 is the first appearance of insect in Timisoara).

If you make the comparison between OP with green spaces and parks, we can see in the graph as in OP/Timisoara1 and other points, OP/Resita and OP/Dr.Turnu Severin there are some differences. In OP/Timisoara1, the values show that the colonies and that of larvae is higher, respectively over 20 colonies and 50 larvae on the plants. In OP/Resita and OP/Dr. Turnu Severin athe values were lower, but it's not close to the minimum level, over $5 \mathrm{col}$. and 20 larvae/plants in OP/Resita while in OP/ Dr.Turnu Severin these were over $10 \mathrm{col}$. and 30 larvae/plants. No colony of larvae was not found in OP-Caransebes.

Comparing the points of agricultural material (vineyards and orchards) the result is quite

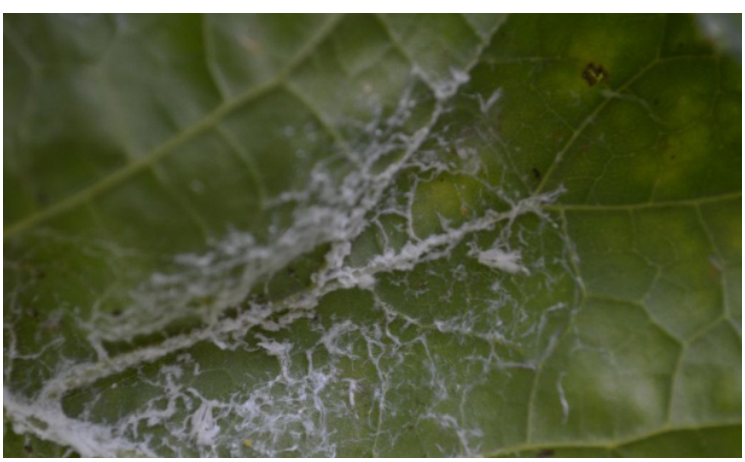

Fig. 2 Larvae and their waxy secretion on leaves

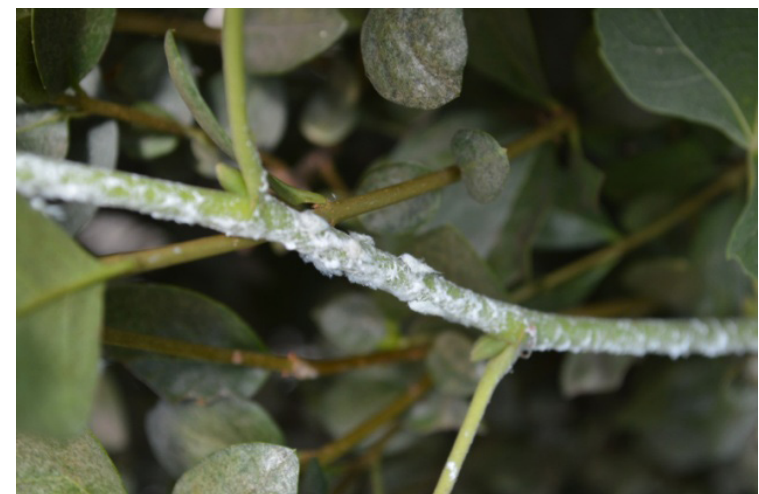

Fig. 4 Colonies of larvae on shoots (strongly affected plants) 
obvious, in OP/Tirol no colony of larvae was found in the observed period, while in OP/Timisoara2 the values were smooth high (over 15 colonies and over 40 larvae present on the plants).

Damages. There are various hypotheses concerning the effects produced by this invasive species. After some researchers (Lucchi and Santini, 2001; Kahrer et. al., 2009) cicada can cause both direct and indirect damage.

In our studies we found that the symptomatology describes in specialty literature is similary. So, direct damage can be associated with local characteristic discoloration with is achieved through mouth adapted for stung and sucked.

Indirect damage is caused by the presence of waxy secretion filamentous of color white- snow (Fig. 1, Fig. 2, Fig. 3,). In case of strong infestation, leaves, fruits, bunches of grapes, stems and shoots have been strongly affected (Fig. 4).

Fig. 1,2,3,4 Aspect of indirectand direct damages on several host plants in some places (parks, green spaces, vineyards) from western Romania

\section{CONCLUSION}

The invasive insect Metcalfa pruinosa is in installation period in our country, which is why we cannot draw a conclusion finals. The sheer volume of work and multiple directions of study we allow only partial conclusions.

Thus we can say that, tha cicada is present both fields, ornamental and agricultural, having a great range of host plants.

Plants with the highest larval infestation are folows: Tilia cordata, Ligustrum vulgare, Catalpa bignonioides; Fraxinus excelsior, Ficus carica, Hibiscus syriacus, Juglans nigra, Acer platanoides, Acer campestre, Acer negundo, Rosa sp, Vitis vinifera and Persica vulgaris. These presented both forms, weak and strongly attack.

Regarding populational level of the larvae and colonies present in the observation points, far as the in OP/Timisoara values are higher than in other places (over 20 colonies and 50 larvae on the plants).

Not in all observation places were found larval colonies of Metcalfa pruinosa.

Acknowledgments. We want to thank the authorities in charge of parks and green spaces from each location where studies were made. Also, to the voluntary persons for that we have helped to periodic readings.

\section{REFERENCES}

1. Alma A, Ferracini C, and Burgio G (2005). Development of sequential plan to evaluate Neodryinus typhlocybae (Ashmead) (Hymenoptera: Drynidae) population associated with Metcalfa pruinosa (Say) (Homoptera: Flatidae) infestation in Northwester Italy, Biological controlparasitoids and predatoris 34 (4): 819-824.

2. Chittenden FH (1900). Notes on two species of "lightning [sic] hoppers." United States Department of Agriculture, Division of Entomology. Bulletin 22:98-99.

3. Drosopoulos A, Broumas T, and Kapothanassi V (2004). Metcalfa pruinosa (Hemiptera, Auchenorrhyncha: Flatidae) an undesirable new species in the insect fauna of Greece. Annals of the Benaki Phytopathological Institute 20(1): 49-51.

4. Grozea I, Gogan A, Vîrteiu AM, Grozea A, Ştef R, Molnar L, Cărăbeț A, Dinnesen S (2011). Metcalfa pruinosa Say (insecta: homoptera: flatidae): A new pest in Romania. African Journal of Agricultural Research 6 (27):58705877.

5. Kahrer A, Strauss G, Stolz M, Moosbeckhofer R (2009). Beobachtungen zu Faunistik und Biologie der vor kurzem nach Österreich eingeschleppten Bläulingszikade (Metcalfa pruinosa). Beiträge zur Entomofaunistik 10: 1730 .

6. Kim Y, Kim M, Hong KJ, Lee S (2011). Outbreak of an exotic flatid, Metcalfa pruinosa (Say) (Hemiptera: Flatidae), in the capital region of Korea. Journal of Asia-Pacific Entomology 14: 473-478.

7. Lauterer P (2002). Citrus flatid planthopper - Metcalfa pruinosa (Hemiptera: Flatidae), a new pest of ornamental horticulture in the Czech Republic. Plant Protect. Sci. 38: 145-148.

8. Lucchi A, Santini L (2001). Aspetti fisiologici e morfofunzionali in Metcalfa pruinosa (Homoptera: Fulgoroidea) con riferimento agli effetti prodotti sulle produzioni agricole e sulle alberature ornamentali. Atti dell'Accad. Nazionale Ital. Entomol. Rendiconti 131 - 147.

9. Metcalf ZP, Bruner SC (1948). Cuban Flatidae with new species from adjacent regions. Annals of the Entomological Society of America 41: 63-118.

10. Preda C, Skolka M (2011). Range Expansion of Metcalfa pruinosa (Homoptera: Fulgoroidea) in Southeastern Europe. Ecologia Balkanica 3:79-87.

11. Sivic F (1991). Medeci skrzat ze v Slovenii. Moj Mali Svet 23 (10): 24-25.

12. Trenchev G, Ivanova I, Nikolov P, Trencheva $K$ (2006). Metcalfa pruinosa (Say 1830) new pest and new species in Bulgaria. 70th Anniversary of Plant Protection Institute and Annual Balkan Week of Plant Health :39.

13. Van Duzee EP (1923). Family Fulgoridae. In: Britton WE, ed. Guide to the Insects of Connecticut, Part IV: The Hemiptera or Sucking Insects of Connecticut. State of Connecticut Public Document 47. State Geological and Natural History Survey Bulletin 34:24-55. 
14. Weese AO (1924). Animal ecology of an Illinois elm-maple forest. Illinois Biological Monographs 9(4):7-93.

15. Willson SW, McPherson JE (1981). Life histories of Anormenis septentrionalis, Metcalfa pruinosa, and Ormenoides venusta with descriptions of immature stages. Ann. Entomol. Soc. America 74 (3): 299-311.
16. Wilson SW, Lucchi A (2000). Aspetti sistematici, corologici, ecologici. In: A. Lucchi, La Metcalfa negli ecosistemi taliani, Agenzia Regionale per lo Sviluppo e l'Innovazione nel settore Agricolo-forestale: 13-28.

17. Zangheri S, Donadini P (1980). Comparsa nel Veneto di un Omottero nearctico Metcalfa pruinosa Say (Homoptera, Flatidae). Redia 63: 301-305. 